\title{
Advanced Flue Gas Desulfurization (AFGD) Demonstration Project A DOE Assessment
}

August 2001

U.S. Department of Energy

National Energy Technology Laboratory

P.O. Box 880, 3610 Collins Ferry Road

Morgantown, WV 26507-0880

and

P.O. Box 10940, 626 Cochrans Mill Road

Pittsburgh, PA 15236-0940

website: www.netl.doe.gov
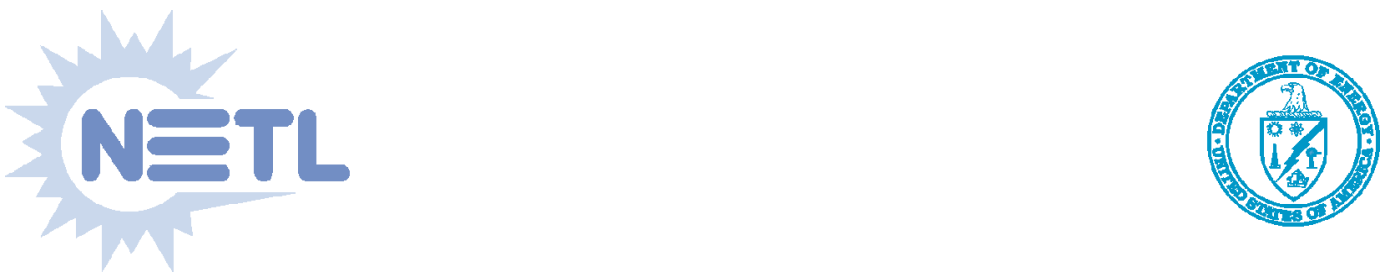


\section{Disclaimer}

This report was prepared as an account of work sponsored by an agency of the United States Government. Neither the United States Government nor any agency thereof, nor any of their employees, makes any warranty, express or implied, or assumes any legal liability or responsibility for the accuracy, completeness, or usefulness of any information, apparatus, product, or process disclosed, or represents that its use would not infringe privately owned rights. Reference therein to any specific commercial product, process, or service by trade name, trademark, manufacturer, or otherwise does not necessarily constitute or imply its endorsement, recommendation, or favoring by the United States Government or any agency thereof. The views and opinions of authors expressed therein do not necessarily state or reflect those of the United States Government or any agency thereof. 


\section{Contents}

Executive Summary $\ldots \ldots \ldots \ldots \ldots \ldots \ldots \ldots \ldots \ldots \ldots \ldots$

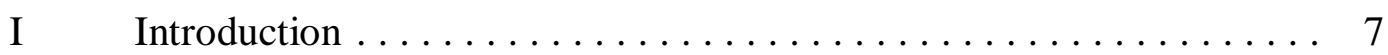

II Technical and Environmental Assessment $\ldots \ldots \ldots \ldots \ldots \ldots \ldots 8$

II.A Promise of the Technology $\ldots \ldots \ldots \ldots \ldots \ldots \ldots \ldots, 8$

II.A.1 Conventional FGD Processes $\ldots \ldots \ldots \ldots \ldots \ldots \ldots$

II.A.2 AFGD Process $\ldots \ldots \ldots \ldots \ldots \ldots \ldots \ldots \ldots \ldots$

II.B Process Description $\ldots \ldots \ldots \ldots \ldots \ldots \ldots \ldots \ldots \ldots$

II.C Project Objectives/Results $\ldots \ldots \ldots \ldots \ldots \ldots \ldots \ldots \ldots, 11$

II.D Environmental Performance $\ldots \ldots \ldots \ldots \ldots \ldots \ldots \ldots . \ldots 12$

II.E Post-Demonstration Achievements . . . . . . . . . . . . 12

III Operating Capabilities Demonstrated $\ldots \ldots \ldots \ldots \ldots \ldots \ldots \ldots . \ldots$

III.A Size of Unit Demonstrated $\ldots \ldots \ldots \ldots \ldots \ldots \ldots \ldots \ldots . \ldots 13$

III.B Performance Level Demonstrated . . . . . . . . . . . . . . 13

III.C Major Operating and Design Variables Studied ............ 14

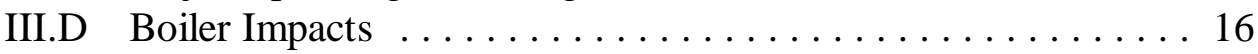

III.E Commercialization of the Technology .............. 16

III.E.1 Current Status . . . . . . . . . . . . . . . . . . . . . 16

III.E.2 Future Work . . . . . . . . . . . . . . . . . 16

IV $\quad$ Market Analysis . ........................... 18

IV.A Potential Markets ......................... 18

IV.B Economic Assessment of Utility Boiler Applications ......... 18

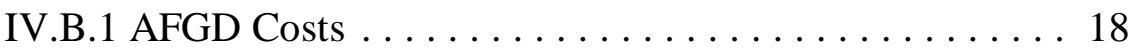

IV.B.2 Comparison With Other Technologies . . . . . . . . 19

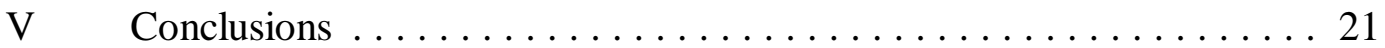

Abbreviations .............................. 22

References ............................. 23

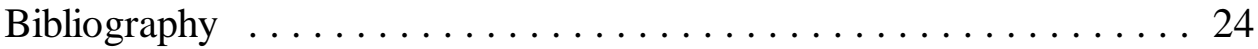




\section{List of Figures and Tables}

Figure Page

1 Pure Air Advanced Flue Gas Desulfurization Process . . . . . . . . . . . 9

2 Absorber Module . . . . . . . . . . . . . . . . . . . . . . . 10

3 Effect of Slurry Circulation on $\mathrm{SO}_{2}$ Removal Efficiency . . . . . . . . . 14

4 Effect of Stoichiometric Ratio on $\mathrm{SO}_{2}$ Removal Efficiency . . . . . . . 15

5 Effect of Liquid/Gas Ratio on $\mathrm{SO}_{2}$ Removal Efficiency . . . . . . . . . 15

Table

Page

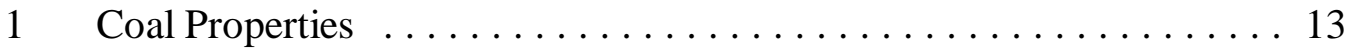

2 Summary of Performance and Cost Data $\ldots \ldots \ldots \ldots$ 


\section{Executive Summary}

This document serves as a U.S. Department of Energy (DOE) post-project assessment of the Clean Coal Technology (CCT) Round II Advanced Flue Gas Desulfurization (AFGD) Demonstration Project, conducted by Pure Air. Pure Air is a general partnership between Air Products and Chemicals, Inc., and Mitsubishi Heavy Industries America, Inc. In December 1989, Pure Air entered into an agreement to conduct this study, with Northern Indiana Public Service Company (NIPSCO) as the host and cosponsor. DOE provided 42 percent of the total project funding cost of $\$ 152$ million. The demonstration operations were conducted from June 1992 to June 1995 at NIPSCO's Bailly Generating Station (units 7 and 8) located in Chesterton, Indiana, to treat the combined flue gases from two boilers with a total nameplate capacity of $616 \mathrm{MWe}$.

The AFGD process accomplishes sulfur dioxide $\left(\mathrm{SO}_{2}\right)$ removal in a single absorber which performs three functions: prequenching, absorption of $\mathrm{SO}_{2}$, and oxidation to produce gypsum. The performance objectives of this project were to

- $\quad$ Remove at least 90-percent $\mathrm{SQ}_{2}$, with a target of 95 percent.

- Reduce process cost by one-half that of conventional flue gas desulfurization (FGD).

- $\quad$ Reduce space requirements.

- $\quad$ Produce wallboard-grade gypsum.

These performance objectives were met except for process cost which was reduced to 63 percent of conventional FGD cost. The $\mathrm{SO}_{2}$ removal target was exceeded. For the five midwestern bituminous coals tested, with sulfur contents ranging from 2.21 to $4.73 \mathrm{wt} \% \mathrm{SO}_{2}$ removal efficiency averaged 94 percent, with a maximum of over 98 percent. The demonstration facility was operated for about 26,300 hours, with system availability of 99.5 percent. Over 210,000 tons of wallboard-grade gypsum were produced, having an average purity of 97.2 percent.

Costs were estimated for a 500-MWe AFGD unit, using a projected process design which incorporates improvements based on experience gained from the demonstration project. The coal feed is assumed to contain $3 \mathrm{wt} \%$ sulfur, and $\mathrm{SO}_{2}$ emissions are assumed to be reduced by 90 percent. The capital cost is $\$ 111 / \mathrm{kW}$. For a 15-year project life, the levelized cost on a current-dollar basis is 5.3 mills/ $\mathrm{kWh}$, which is equivalent to $\$ 245 /$ ton of $\mathrm{SO}_{2}$ removed. The levelized cost for AFGD is about 63 percent of that for conventional wet limestone desulfurization. This is a significant cost reduction, approaching the target value of 50 percent. Space requirements for AFGD are substantially lower than those for conventional FGD processes. 
The project received two major awards: the Outstanding Engineering Achievement award, from the National Society of Professional Engineers in 1992; and the Powerplant of the Year award from Power magazine in 1993, for demonstrating advanced limestone FGD technology with innovations in wastewater treatment and gypsum production.

The AFGD unit remains in operation at the Bailly Station, where it is performing very well. With increasingly stringent air quality regulations, AFGD technology should be a major contender in a growing market for flue gas cleanup. In addition, the innovative use of gypsum by-product in wallboard manufacture has established a new trend; synthetic gypsum produced at FGD facilities has become the preferred feedstock for wallboard manufacture because its uniform properties simplify manufacturing operations for existing users . 


\section{Introduction}

The goal of the U.S. Department of Energy (DOE) Clean Coal Technology (CCT) program is to furnish the energy marketplace with a number of advanced, more efficient, and environmentally responsible coal utilization technologies through demonstration projects. These projects seek to establish the commercial feasibility of the most promising advanced coal technologies that have developed beyond the proof-of-concept stage.

This document serves as a DOE post-project assessment of the of the CCT Round II Advanced Flue Gas Desulfurization (AFGD) Demonstration Project, as described in a Report to Congress (U.S. Department of Energy 1989). In December 1989, Pure Air and Northern Indiana Public Service Company (NIPSCO) entered into a cooperative agreement to conduct the study. Pure Air is a general partnership between Air Products and Chemicals, Inc., and Mitsubishi Heavy Industries America, Inc. Subsequently, Pure Air on the Lake, L.P., was organized as a project company of Pure Air to implement the project. NIPSCO served as the host at its Bailly Generating Station. DOE provided 42 percent of the total project cost of $\$ 152$ million.

The demonstration operations were started in June 1992 and completed in June 1995. The independent evaluation contained herein is based primarily on information from the project Final Report (Pure Air 1996), as well as sources listed in the bibliography.

The AFGD process removes sulfur dioxide $\left(\mathrm{SO}_{2}\right)$ in a single absorber which performs three functions: prequenching, absorption, and oxidation to wallboard grade gypsum.

The Clean Air Act, enacted in 1970 and amended in 1977, established New Source Performance Standards (NSPS) for emissions of $\mathrm{SO}_{2}$, nitrogen oxides $\left(\mathrm{NO}_{\mathrm{X}}\right)$, and particulates from stationary coal-fired power plants. These regulations were made more stringent in the Clean Air Act Amendments (CAAA) of 1990.

The host site chosen for this CCT demonstration project, NIPSCO's Bailly Generating Station, is located along the shore of Lake Michigan approximately 12 miles northeast of Gary, Indiana. The station is bordered by industrial installations and by the Indiana Dunes National Lakeshore.

The performance objectives of this project were to

- Remove at least 90-percent SQ, with a target of 95 percent.

- $\quad$ Reduce process cost by one-half that of conventional flue gas desulfurization (FGD).

- $\quad$ Reduce space requirements.

- $\quad$ Produce wallboard-grade gypsum. 


\section{Technical and Environmental Assessment}

\section{II.A Promise of the Technology}

\section{II.A.I Conventional FGD Processes}

Conventional wet-process systems for flue gas desulfurization use an aqueous slurry of limestone $\left(\mathrm{CaCO}_{3}\right)$ as the reagent in an absorber, or scrubber, which is usually a vertical vessel in which the flue gas is contacted with the slurry. The flow of gas, which is normally countercurrent to the liquid, is limited by the mass transfer characteristics of the system, thereby determining the cross sectional area of the scrubber. These vessels tend to be quite large in practice. The reaction product exiting the bottom of the scrubber is an aqueous sludge containing calcium sulfite $\left(\mathrm{CaSO}_{3}\right)$ and calcium sulfate $\left(\mathrm{CaSO}_{4}\right)$, which is sent to a disposal pond or landfill after partial dewatering. Such ponds require large areas of land and are unsightly.

In addition to the disposal problem, another disadvantage of conventional processes is potential scaling and plugging of the scrubber and auxiliary piping resulting from the presence of these two calcium salts. This in turn requires frequent shutdowns for maintenance and results in the need for a spare scrubber module of equivalent capacity to permit uninterrupted treatment of the flue gas while the main scrubber is off line. Alternative processes have been developed in which the sludge is reacted with oxygen to convert the $\mathrm{CaSO}_{3}$ to $\mathrm{CaSO}_{4}$ (gypsum), which can be sold as wallboard or used in cement manufacture. Generally this step requires a separate reaction vessel, using air as the oxidizing agent.

\section{II.A.2 AFGD Process}

The Pure Air project was undertaken to evaluate the technical and economic feasibility of using the AFGD process to remove $\mathrm{SO}_{2}$ from the flue gas of a coalfired boiler in a single, highly efficient contacting device which provides prequenching of the flue gas, absorption, and oxidation. Pulverized limestone is injected directly into the absorber. Oxidation is achieved by means of an air rotary sparger (ARS), which provides sufficient agitation and air distribution to achieve essentially complete oxidation of sulfite. The process incorporates a unique agglomeration step to enhance the physical properties of the gypsum by-product. The resulting product, called PowerChip ${ }^{\circledR}$ gypsum, is easier for existing users to handle in their wallboard manufacturing operations. In addition, the AFGD system includes a wastewater evaporation system (WES), which eliminates wastewater discharge by evaporating the residual water using heat contained in the flue gas. 


\section{II.B Process Description}

A schematic flowsheet showing the AFGD process is given in Figure 1. The process involves reaction of $\mathrm{SO}_{2}$ with water to form sulfurous acid $\left(\mathrm{H}_{2} \mathrm{SO}_{3}\right)$, which in turn is oxidized to sulfuric acid $\left(\mathrm{H}_{2} \mathrm{SO}_{4}\right)$. The latter reacts with limestone to form gypsum. The primary equations are as follows:

$$
\begin{array}{lll}
\mathrm{SO}_{2}+\mathrm{H}_{2} \mathrm{O} & \rightarrow & \mathrm{H}_{2} \mathrm{SO}_{3} \\
\mathrm{H}_{2} \mathrm{SO}_{3}+1 / 2 \mathrm{O}_{2} & \rightarrow & \mathrm{H}_{2} \mathrm{SO}_{4} \\
\mathrm{CaCO}_{3}+\mathrm{H}_{2} \mathrm{SO}_{4}+\mathrm{H}_{2} \mathrm{O} & \rightarrow & \mathrm{CaSO}_{4} \cdot 2 \mathrm{H}_{2} \mathrm{O}+\mathrm{CO}_{2}
\end{array}
$$

Alternatively, the reaction path can be described as follows, with the same net result:

$$
\begin{array}{lll}
\mathrm{SO}_{2}+\mathrm{H}_{2} \mathrm{O} & \rightarrow & \mathrm{H}_{2} \mathrm{SO}_{3} \\
\mathrm{CaCO}_{3}+\mathrm{H}_{2} \mathrm{SO}_{3} & \rightarrow & \mathrm{CaSO}_{3}+\mathrm{CO}_{2}+\mathrm{H}_{2} \mathrm{O} \\
\mathrm{CaSO}_{3}+1 / 2 \mathrm{O}_{2}+2 \mathrm{H}_{2} \mathrm{O} & \rightarrow & \mathrm{CaSO}_{4} \cdot 2 \mathrm{H}_{2} \mathrm{O}
\end{array}
$$

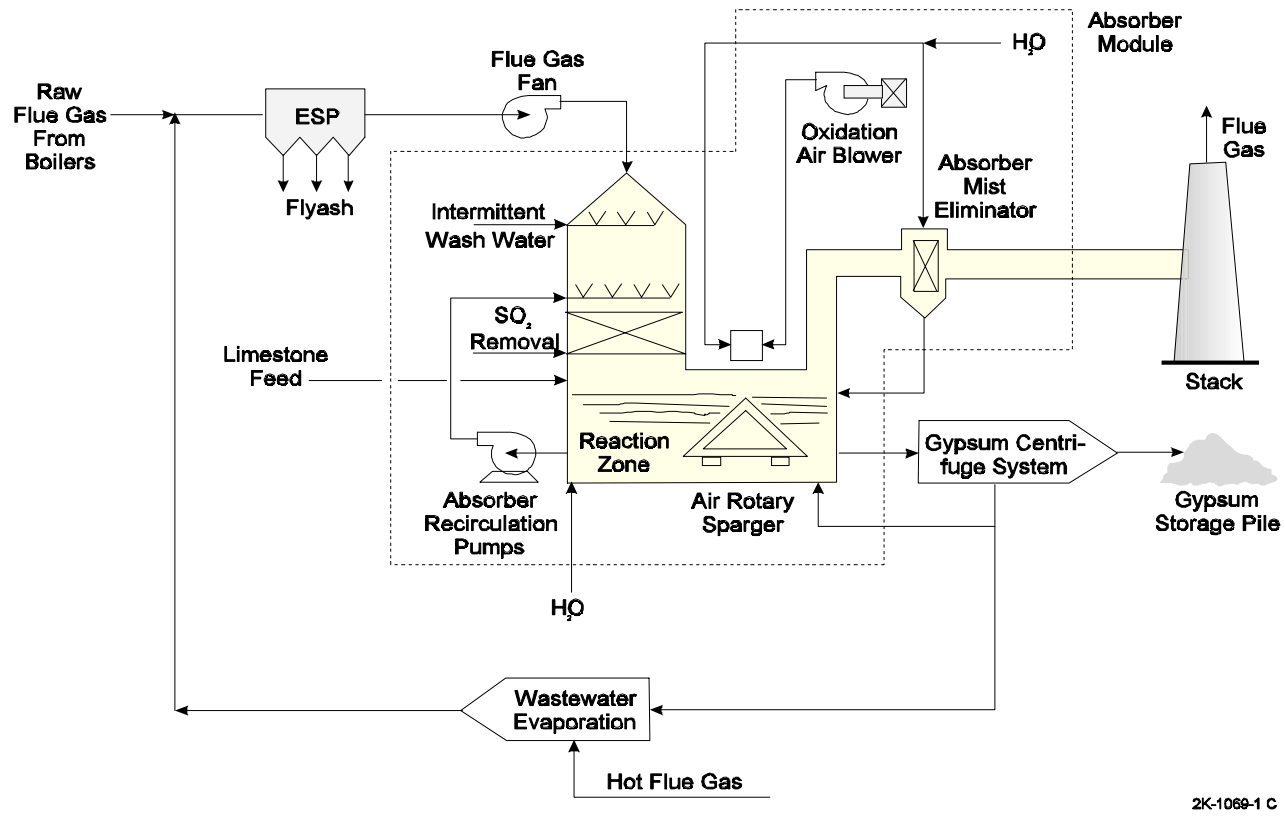

Figure 1. Pure Air Advanced Flue Gas Desulfurization Process

The Pure Air facility utilizes a single resin-lined absorber or "scrubber" module to treat all of the flue gas from the Bailly Station's two coal-fired boilers. There is no backup or spare scrubber. The absorber operates with cocurrent flow of flue gas and scrubbing slurry, with two levels of slurry distribution. The absorber design includes a large gas-liquid disengagement zone, which is conducive to a relatively 
high flue gas flow-rate of about $20 \mathrm{ft} / \mathrm{sec}$, resulting in a compact absorber design. By using high-efficiency open-grid packing, tower height is also reduced.

The absorber performs three separate functions in the same vessel: prequenching the flue gas, absorption, and oxidation. In older FGD systems, these functions required separate vessels. Additional space- and cost-saving features include

- A non-pressurized slurry distribution system, requiring approximately 30 percent less recirculation-pump power than conventional countercurrent spray towers.

- $\quad$ Fountain-like flow that does not generate a fine mist, thereby reducing mist eliminator loading by as much as 95 percent compared to countercurrent designs.

- Use of a dry pulverized limestone injection system, eliminating the need for ball mills, tanks, pumps, and other equipment associated with on-site wet grinding systems.

The absorber includes the ARS concept, which combines the functions of mixing and air distribution. There are two ARSs installed in the absorber at Bailly Station. In conventional FGD systems with forced oxidation, mixing is done by agitators in the scrubber while oxidation takes place in a separate vessel with a fixed air sparger. The ARS system provides higher oxygen utilization, improved mixing, lower agitation power and reduced maintenance. A schematic diagram of the absorber is given in Figure 2.

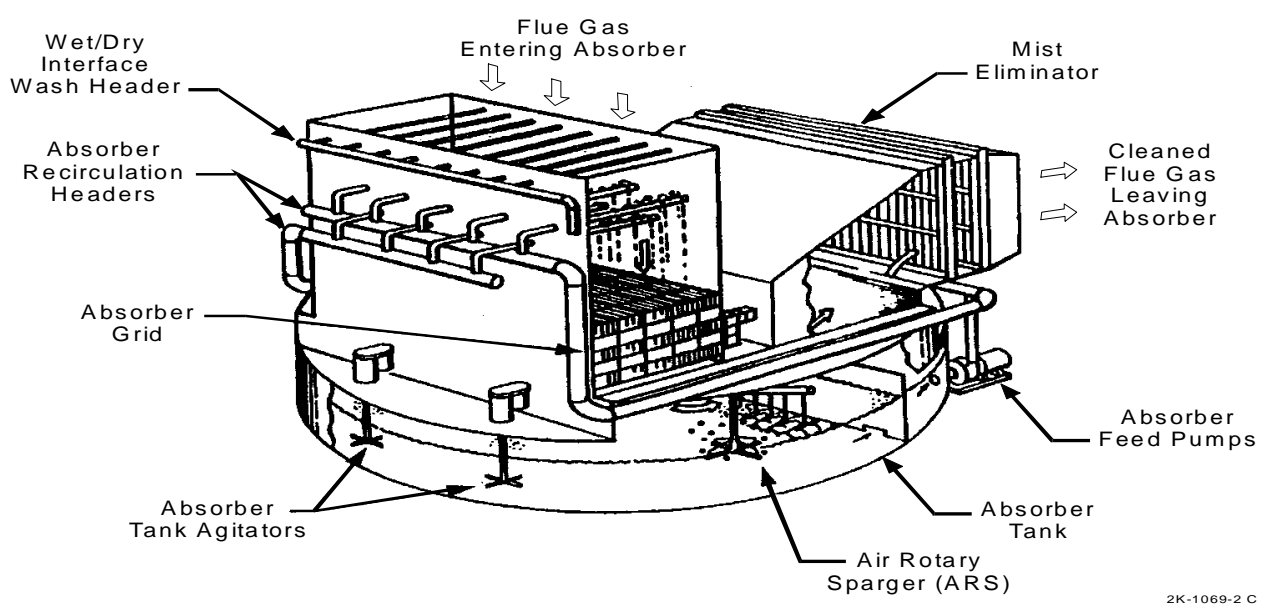

Figure 2. Absorber Module

Raw gypsum slurry is pumped to a batch centrifuge, where water is removed and the cake is washed to recover wallboard-grade gypsum. The major portion of the filtrate is recycled to the absorber. The net liquid effluent is treated in the WES, which involves injection into the flue gas duct upstream of the existing electrostatic 
precipitator (ESP). The hot flue gas evaporates the water and the dissolved solids are collected in the ESP along with the fly ash.

The gypsum by-product from the AFGD process has the consistency of wet sand, which is not conducive to transportation or handling by existing wallboard manufacturing equipment. The CCT demonstration project included the development of the proprietary PowerChip ${ }^{\circledR}$ gypsum agglomeration process. This process utilizes a compression mill, operating at a unique combination of temperature and pressure, to reformulate and modify the physical structure of the gypsum to produce stable, semi-dry agglomerated flakes resembling the properties of natural gypsum. The resulting by-product can be transported and handled as easily as the natural material. PowerChip ${ }^{\circledR}$ gypsum is produced in relatively dry, consistently sized chips which do not freeze together in cold weather.

Gypsum made at the Bailly Station is sold to United States Gypsum Company (U.S. Gypsum) for wallboard manufacture at its East Chicago, Indiana plant. This plant was the first facility in North America to produce wallboard from 100percent FGD gypsum. Since production began, U.S. Gypsum has taken the entire output of the Bailly AFGD unit. During the 3-year demonstration, gypsum production exceeded 210,000 tons. Because there is added cost associated with running PowerChip ${ }^{\circledR}$ gypsum, and because U.S. Gypsum is capable of handling the normal production of gypsum from Bailly Station, only a portion of the byproduct was converted to PowerChip ${ }^{\circledR}$ gypsum.

Another feature of this project is a novel business concept whereby Pure Air is the owner of the AFGD unit, operating the system for the utility under a service contract. Under this agreement, Pure Air is responsible for (a) procurement of limestone, (b) processing the flue gas and returning it to the stack, (c) delivery of gypsum to the wallboard manufacturer, and (d) treatment of the wastewater.

\section{II.C Project Objectives/Results}

The goal of this project was to demonstrate AFGD retrofit technology for reducing $\mathrm{SO}_{2}$ emissions from coal-fired utility boilers. The project was designed to confirm pilot plant results and to develop scale-up procedures necessary for commercial application of the technology, as well as to resolve those technical issues that could not be adequately addressed in an engineering study or in pilotscale tests. Specific objectives were to

- $\quad$ Remove at least 90-percent $\mathrm{SO}_{2}$, with a target of 95 percent.

- $\quad$ Reduce process cost by one-half that of conventional flue gas desulfurization (FGD).

- $\quad$ Reduce space requirements.

- $\quad$ Produce wallboard-grade gypsum. 
The $\mathrm{SO}_{2}$ removal target was exceeded. $\mathrm{SO}_{2}$ removal efficiency during the test program averaged 94 percent, with a maximum of over 98 percent. The demonstration facility was operated for about 26,300 hours, with system availability of 99.5 percent.

Economic calculations (discussed in section IV.B) show a levelized cost for AFGD at about 63 percent of that for a conventional wet limestone FGD process. This is a significant cost reduction, and is in the range of the target value of 50 percent.

The space requirements for AFGD are not discussed in detail in the documentation for this project, but they are substantially lower than those for conventional FGD processes because of smaller equipment and the minimum use of spares. U.S. Gypsum purchased the entire output of 210,000 tons of wallboard-grade gypsum, which had an average purity of 97.2 percent.

\section{II.D Environmental Performance}

The AFGD demonstration project showed the capability of AFGD for reducing $\mathrm{SO}_{2}$ emissions at coal-burning power plants. With a coal sulfur content of 3.0 percent and a 94-percent $\mathrm{SO}_{2}$ removal rate, the facility reduces emissions by about 68,000 tons/yr. The flue gas $\mathrm{SO}_{2}$ content is $0.48 \mathrm{lb} /$ million Btu (MBtu), which is considerably lower than the NSPS of $0.6 \mathrm{lb} / \mathrm{MBtu}$.

With the AFGD unit installed, the Bailly Station became the first power plant among CAAA Phase I affected units to meet the $\mathrm{SO}_{2}$ standards using FGD technology. Recovering wallboard-grade gypsum as a by-product eliminates the need for solid waste disposal. In addition, use of the WES concept results in zero discharge of liquids from the plant.

\section{II.E Post-Demonstration Achievements}

The AFGD unit at Bailly Station remains in service and will continue to operate for the balance of the 20-year contract life. As a result of the success of this project, a new venture was formed in 1994 between Pure Air of Manatee, L.P., and Florida Power and Light Company to provide 1600 MWe of scrubbing capability at its Manatee Power Plant, using the AFGD process and the same own-and-operate concept as at Bailly Station. The intent was to burn a fuel imported from Venezuela; Orimulsion is an emulsified bitumen material similar to heavy fuel oil but having a sulfur content of 3 percent or more, comparable to coal. The Manatee project was abandoned because of a ban on the use of Orimulsion in Florida.

The project received two major awards: the Outstanding Engineering Achievement award, from the National Society of Professional Engineers in 1992; and the Powerplant of the Year award from Power magazine in 1993, for demonstrating advanced limestone FGD technology with innovations in wastewater treatment and gypsum production. 


\section{Operating Capabilities Demonstrated}

\section{III.A Size of Unit Demonstrated}

The demonstration project was conducted at NIPSCO's Bailly Generating Station, which has two coal-fired boilers. Unit 7, permitted at 183 MWe (gross), began operation in 1962, and unit 8, permitted at 345 MWe (gross), began operation in 1968. The combined flue gas, representing $528 \mathrm{MWe}$, is treated in the AFGD scrubber. The combined nameplate rating of units 7 and 8 is 616 MWe (gross), and the scrubber was designed to accommodate the higher capacity.

Over the three-year demonstration period, the boilers were fired with five Midwestern bituminous coals having a sulfur content ranging from 2.21 to 4.73 percent. Coal properties are given in Table 1.

Table 1. Coal Properties

(Coal Source: Midwestern bituminous; Ultimate Analysis, wt\%)_

\begin{tabular}{||l||r|r|r|r|r||}
\hline Coal No. & I & II & III & IV & V \\
\hline \hline Carbon & 66.77 & 61.46 & 62.03 & 59.02 & 69.39 \\
\hline Hydrogen & 4.51 & 4.38 & 4.09 & 4.36 & 4.94 \\
\hline Nitrogen & 1.44 & 1.23 & 1.22 & 1.26 & 1.17 \\
\hline Sulfur & 2.21 & 2.90 & 3.21 & 3.78 & 4.73 \\
\hline Oxygen & 6.73 & 7.43 & 8.18 & 7.18 & 5.64 \\
\hline Chlorine & 0.14 & 0.10 & 0.06 & 0.03 & 0.07 \\
\hline Moisture & 8.63 & 12.89 & 11.12 & 13.69 & 4.74 \\
\hline Ash & 9.57 & 9.61 & 10.09 & 10.68 & 9.32 \\
\hline Total & 100.00 & 100.00 & 100.00 & 100.00 & 100.00 \\
\hline \hline HHV, Btu/lb & 11,932 & 11,022 & 10,874 & 11,000 & 12,700 \\
\hline \hline
\end{tabular}

\section{III.B Performance Level Demonstrated}

The AFGD unit at Bailly Station achieved an average $\mathrm{SO}_{2}$ emissions reduction of 94 percent, with a maximum of over 98 percent. Availability was 99.5 percent. Over 210,000 tons of gypsum, having a purity of 97.2 percent, were produced and sold to a local wallboard manufacturer. 
To achieve these results, some modifications to the initial design were required, primarily in materials of construction. At the wet/dry interface within the absorber vessel, it was necessary to install a C-276 alloy cladding over carbon steel. The high pressure nozzles in the original WES were replaced with two-fluid nozzles which provided better droplet size distribution, eliminating the problem of excessive accumulation of solids in the ductwork.

\section{III.C Major Operating and Design Variables Studied}

The variables studied in the test program were (a) sulfur content of the coal, (b) slurry recirculation rate, (c) stoichiometric ratio (SR) of calcium sorbent to sulfur removed, and (d) liquid to gas (L/G) ratio in the absorber. The results are summarized below.

- Effects of Recirculation Rate and Coal Sulfur Content: At a constant $\mathrm{SR}$ and coal sulfur content, $\mathrm{SO}_{2}$ removal efficiency increases with increasing slurry flow rate. For example, at an SR of 1.045 and a coal sulfur content of 2.25 percent, $\mathrm{SO}_{2}$ removal efficiency increases from 90 percent at a recirculation rate of 50 percent of design to about 97 percent at 100 percent of design. $\mathrm{SO}_{2}$ removal efficiency was found to decrease with increasing coal sulfur content. It would be expected that $\mathrm{SO}_{2}$ removal efficiency would be greater at higher coal sulfur content because of the greater driving force. Since this was not the case, an alternative explanation might be that residence time is limiting. The Final Report (Pure Air 1996) does not address this issue. The results are shown in Figure 3.

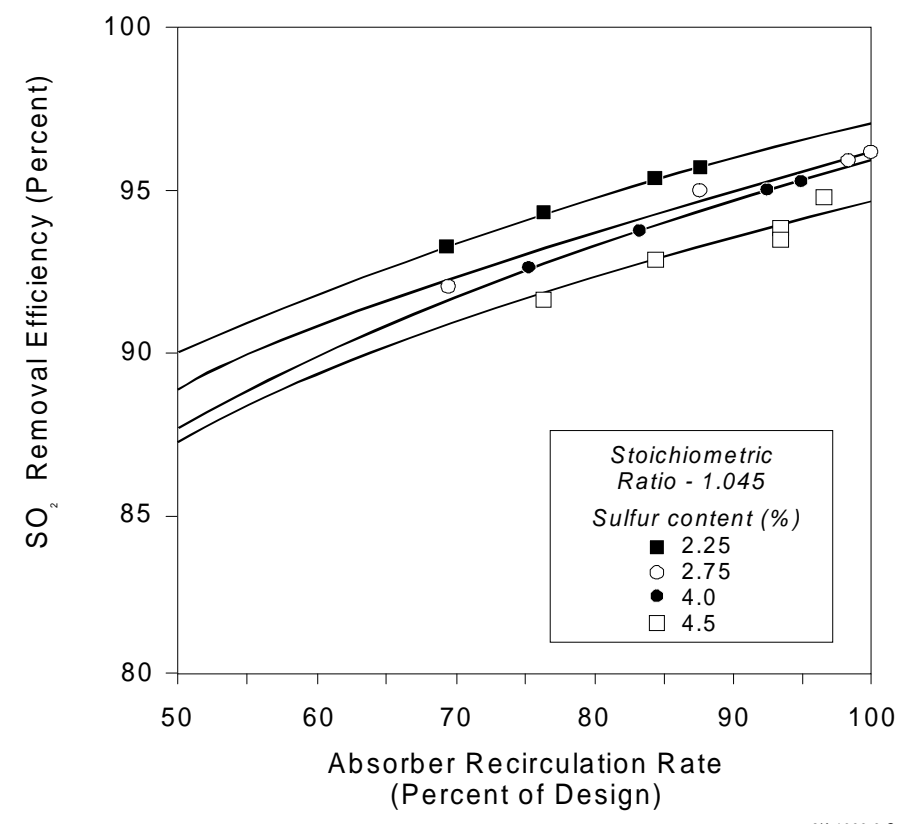

Figure 3. Effect of Slurry Circulation on $\mathrm{SO}_{2}$ Removal Efficiency (100\% Boiler Load) 
Effects of Stoichiometric Ratio and L/G Ratio: At a constant L/G ratio and coal sulfur content, $\mathrm{SO}_{2}$ removal increases with increasing SR. For example, at an $\mathrm{L} / \mathrm{G}$ ratio of 76 percent of design, $\mathrm{SO}_{2}$ removal efficiency increases from about 91 percent at an SR of 1.01 to about 98 percent at an SR of 1.10. These results are shown in Figure 4. Similar patterns exist for other L/G ratios, as shown in Figure 5.

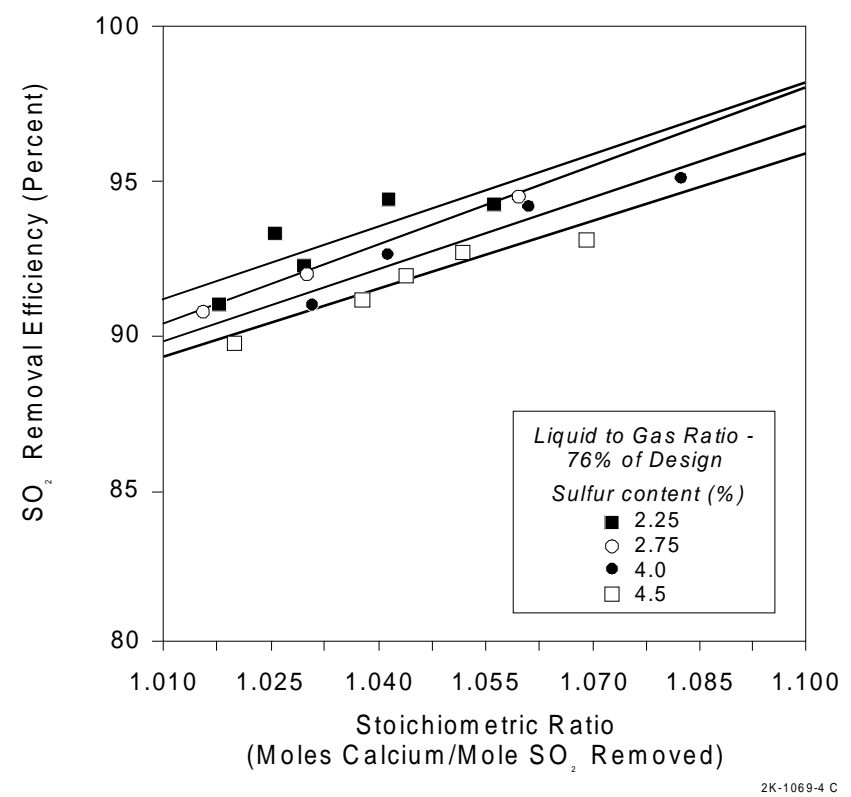

Figure 4. Effect of Stoichiometric Ratio on $\mathrm{SO}_{2}$ Removal Efficiency (100\% Boiler Load)

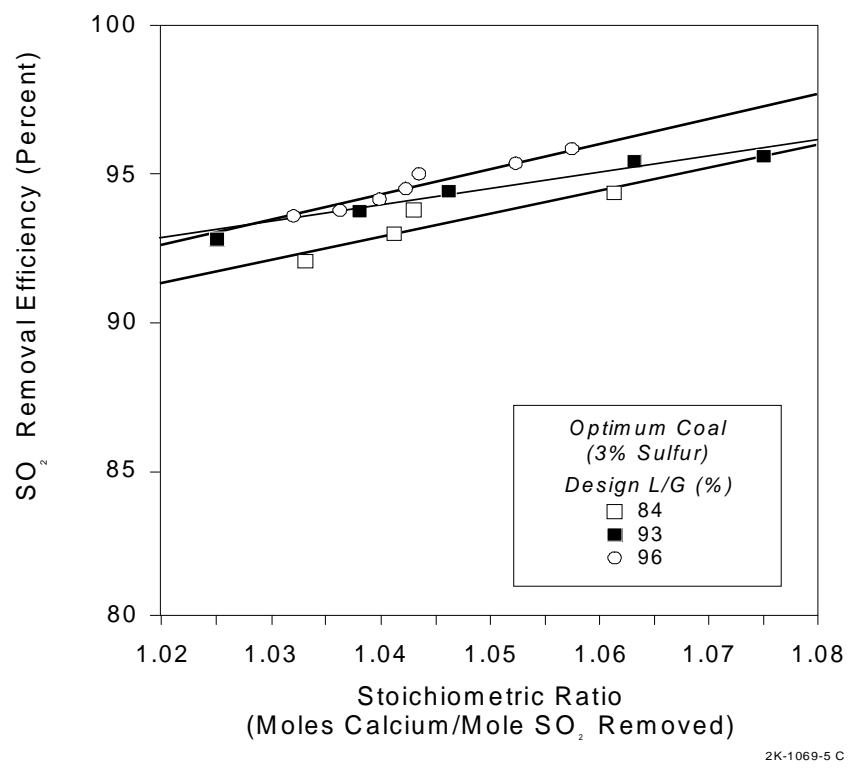

Figure 5. Effect of Liquid/Gas Ratio on $\mathrm{SO}_{2}$ Removal Efficiency (100\% Boiler Load) 


\section{III.D Boiler Impacts}

Operation of the Pure Air AFGD unit, which treats flue gas downstream of the boiler, had no effect on boiler performance. As indicated above, use of the AFGD process brought the generating station into compliance with air pollution regulations.

\section{III.E Commercialization of the Technology}

\section{III.E.1 Current Status}

The AFGD unit at Bailly Station will continue to operate for the remainder of the 20-year own-and-operate contract, with Pure Air as the owner of the unit and Air Products as the operator. This facility will reduce $\mathrm{SO}_{2}$ emissions by approximately 68,000 tons/yr. The gypsum by-product will continue to be sold to United States Gypsum Company for manufacture of wallboard.

In April 1994, Pure Air of Manatee, L.P., entered into a contract to provide 1600 MWe of $\mathrm{SO}_{2}$ scrubbing capability at Florida Power \& Light Company's Manatee power plant on the same own-and-operate basis. Although the project did not go forward because of the inability to obtain approval for burning Orimulsion in Florida, the design for the Manatee scrubber features two 800-MWe absorber vessels, PowerChip ${ }^{\circledR}$ gypsum production, and use of the WES concept.

\section{III.E.2 Future Work}

In conventional wet limestone scrubbers, dibasic acids such as adipic acid have been used as reagent additives to enhance $\mathrm{SO}_{2}$ removal performance. Pure Air is evaluating the possible use of dibasic acids in the AFGD process, taking into account effects on capital and operating costs as well as properties of the byproduct gypsum.

Initially, WES operation experienced problems resulting from plugging of the high pressure nozzles. These problems have been solved by use of dual fluid nozzles. Because of ample capacity for wastewater treatment at Bailly Station, the WES is not currently being operated, but the concept was demonstrated to be viable in this project and it most likely would be used in future installations.

Likewise, problems associated with gypsum recovery have been solved, permitting attainment of the goal of zero discharge of waste streams. The PowerChip ${ }^{\circledR}$ system was demonstrated successfully, and is available for use in other applications. Since there is added cost associated with running this system, and 
since United States Gypsum is capable of handling the normal production of gypsum from the Bailly Station, the PowerChip ${ }^{\circledR}$ system is not being operated on a routine basis.

A brown plume has occasionally been observed emanating from the combined unit 7 and unit 8 stack. Studies have identified small amounts of sulfur trioxode $\left(\mathrm{SO}_{3}\right)$ in the flue gas, generated by oxidation of $\mathrm{SO}_{2}$, as the cause of this phenomenon. Since $\mathrm{SO}_{3}$ is not removed in the scrubber, it is necessary to control this pollutant by other methods; one commonly used approach is injection of ammonia into the stack gas. At Bailly Station, NIPSCO has successfully minimized the concentration of $\mathrm{SO}_{3}$ in the flue gas by careful control of boiler variables, thus eliminating the need for ammonia injection. 


\section{Market Analysis}

\section{IV.A Potential Markets}

The AFGD process is potentially applicable to all types of conventional coal-fired boilers including stoker, cyclone, wall-fired and tangentially fired boilers. Pure Air states that the most likely application of AFGD is with boilers above 100 MWe in capacity, since duct scrubbers are favored at lower capacities because of lower capital cost. Of the larger boilers, the most likely retrofit candidates would be those currently burning medium to high sulfur coal that choose to install scrubbers rather than switch fuels.

In the United States, relatively few of the plants regulated under Phase I of the 1990 CAAA have installed scrubbers for $\mathrm{SO}_{2}$ control. A large proportion of these plants have achieved compliance by fuel switching or by purchasing $\mathrm{SO}_{2}$ emission credits. However, the price of emission allowances is increasing, and it is likely that a significant U.S. market for flue gas desulfurization will develop in Phase II. High performance, cost-effective scrubbers will be prime contenders for a share of this market. The international market represents additional opportunities for AFGD.

For the most effective use of all of the features of AFGD, it is essential to identify markets for the gypsum by-product. The Pure Air project has shown that Wallboard manufacture provides the perfect use for synthetic gypsum. Based in part on the success of this project, several new plants are being planned or built to manufacture wallboard from by-product gypsum. In fact, because of its uniform properties, synthetic gypsum has displaced the natural material as the preferred feedstock for wallboard manufacture. Coupled with a shortage of natural gypsum, the market prospects for FGD by-product gypsum appear strong. Another use for FGD by-product gypsum is to combine it with boiler fly ash to make cement. However, cement users tend to be smaller and more numerous, and gypsum specifications for cement are slightly different than for those for wallboard.

As mentioned previously, Pure Air envisions a new market opportunity for AFGD in East Coast power plants involving the use of a low cost, high-sulfur fuel known as Orimulsion. If use of this fuel is approved by state regulatory agencies, desulfurization of the flue gas will be required, and the AFGD process will be a candidate for this purpose.

\section{IV.B Economic Assessment of Utility Boiler Applications}

\section{IV.B.1 AFGD Costs}

The Final Report (Pure Air 1996) includes an economic estimate for a 500-MWe AFGD unit, using a projected process design for the $\mathrm{n}^{\text {th }}$ plant which incorporates 
improvements based on experience gained from the demonstration project. The capital cost includes a 10-percent retrofit allowance, representing moderate retrofit difficulty. The coal feed is assumed to contain $3 \mathrm{wt} \%$ sulfur, with 90-percent $\mathrm{SO}_{2}$ emissions reduction using an SR of 1.04.

The estimated capital cost is $\$ 111 / \mathrm{kW}$ in 1996 dollars. For a 15 -year project life, the levelized cost on a current dollar basis is $5.3 \mathrm{mills} / \mathrm{kWh}$. This is equivalent to $\$ 245 /$ ton of $\mathrm{SO}_{2}$ removed. On a constant dollar basis, the levelized cost is 4.1 mills/kWh, equivalent to $\$ 188 /$ ton of $\mathrm{SO}_{2}$ removed. These economics are given in more detail in Table 2.

Since the design assumes zero discharge, there is no waste disposal expense. The economics include a credit of $\$ 1.00 /$ ton for the by-product gypsum. The economics also assume a credit of $\$ 150 /$ ton for 7379 tons $/ \mathrm{yr}$ of $\mathrm{SO}_{2}$ emission allowances. The allowance price appears realistic in the light of current trends, but the Pure Air Final Report does not explain the basis for selecting the amount of $\mathrm{SO}_{2}$ allowances sold. Credits significantly effect the total levelized cost, and contribute substantially to the favorable economics. The issue of allowance quantities and prices needs to be explored in future evaluations of the AFGD process.

\section{IV.B.2 Comparison With Other Technologies}

The Pure Air Final Report discusses the relative merits of wet and dry scrubbing for $\mathrm{SO}_{2}$ removal. An advantage of AFGD is its capability of achieving 95-percent $\mathrm{SO}_{2}$ removal at reasonable cost. Pure Air provides some quantitative cost comparisons between AFGD and conventional FGD, assuming a 4.3-percent sulfur feed and a 30-year project life (as opposed to the 3.0-percent sulfur feed and 15year project life used in the economic estimate discussed in section IV.B.1, for AFGD alone). Several scenarios are considered, involving a range of plant capacities and assumptions regarding by-product credits and $\mathrm{SO}_{2}$ emission allowances.

At a capacity of $500 \mathrm{MWe}$, the most favorable case for AFGD shows a levelized cost of $\$ 236 /$ ton of $\mathrm{SO}_{2}$ removed compared with $\$ 373 /$ ton for a typical conventional wet process FGD. Thus FGD costs about 58 percent more than AFGD, or, in other words, the AFGD cost is about 63 percent of the conventional process cost. This represents a significant advantage for AFGD and approaches the stated target for AFGD of about one-half the cost of conventional processes.

Insufficient detail is given in the Pure Air report to permit further analysis of these figures. It should be noted that the economic calculations in this comparison include a price of $\$ 300 /$ ton for $\mathrm{SO}_{2}$ emission allowances, which is twice that assumed in the base case. Since emissions credits have a significant effect on the economics, these results must be treated with caution. 
Table 2. Summary of Performance and Cost Data (1996 dollars)

\begin{tabular}{|c|c|c|c|c|}
\hline & \multicolumn{2}{|c|}{$\begin{array}{l}\text { Coal Properties } \\
\text { Higher heating value(HHV) } \\
\end{array}$} & \multicolumn{2}{|l|}{$12,500 \mathrm{Btu} / \mathrm{lb}$} \\
\hline & \multicolumn{2}{|c|}{$\begin{array}{l}\text { Power Plant Attributes With Controls } \\
\text { Plant capacity, net }\end{array}$} & \multicolumn{2}{|l|}{$500 \mathrm{MWe}$} \\
\hline & \multicolumn{2}{|c|}{ Power produced, net } & \multicolumn{2}{|l|}{$2.85 \times 10^{9} \mathrm{kWh} / \mathrm{yr}$} \\
\hline & \multicolumn{2}{|c|}{ Capacity factor } & \multicolumn{2}{|l|}{$65 \%$} \\
\hline & \multicolumn{2}{|l|}{ Coal fed } & \multicolumn{2}{|l|}{$1.14 \times 10^{6}$ tons $/ \mathrm{yr}$} \\
\hline & \multicolumn{2}{|c|}{$\begin{array}{l}\mathrm{SO}_{2} \text { Emissions Control Data } \\
\text { Removal efficiency }\end{array}$} & \multicolumn{2}{|l|}{$90 \%$} \\
\hline & \multicolumn{2}{|c|}{ Emissions without controls } & \multicolumn{2}{|l|}{$4.8 \mathrm{lb} / \mathrm{MBtu}$} \\
\hline & \multicolumn{2}{|c|}{ Emissions with controls } & \multicolumn{2}{|l|}{$.48 \mathrm{lb} / \mathrm{MBtu}$} \\
\hline & \multicolumn{2}{|l|}{$\mathrm{SO}_{2}$ removed } & \multicolumn{2}{|l|}{61,495 tons/yr } \\
\hline & \multicolumn{2}{|c|}{ Gypsum produced } & \multicolumn{2}{|l|}{174,450 tons $/ \mathrm{yr}$} \\
\hline & \multicolumn{2}{|c|}{ Emissions allowances sold } & \multicolumn{2}{|l|}{7,379 tons/yr } \\
\hline & \multicolumn{2}{|c|}{ Total Capital Requirement } & $111 \$ / \mathrm{kW}$ & \\
\hline \multicolumn{2}{|c|}{ Levelized Cost, Current \$ } & Levelization Factor $^{\text {a }}$ & mills/kWh & $\$ /$ ton $\mathrm{SO}_{2}$ Removed \\
\hline \multicolumn{2}{|l|}{ Capital charge } & 0.160 & 3.06 & 142 \\
\hline \multicolumn{2}{|l|}{ Fixed O\&M } & 1.314 & 1.16 & 54 \\
\hline \multicolumn{2}{|l|}{ Variable O\&M } & 1.314 & 1.67 & 78 \\
\hline \multicolumn{2}{|c|}{ Less: Credit for gypsum sales ${ }^{b}$} & 1.314 & -0.08 & -4 \\
\hline \multicolumn{2}{|c|}{ Less: $\mathrm{SO}_{2}$ emission allowances ${ }^{\mathrm{c}}$} & 1.314 & -0.54 & -25 \\
\hline \multicolumn{2}{|l|}{ Total } & & 5.27 & 245 \\
\hline \multicolumn{2}{|c|}{ Levelized Cost, Constant \$ } & Levelization Factor $^{\text {a }}$ & mills/kWh & $\$ /$ ton $\mathrm{SO}_{2}$ Removed \\
\hline \multicolumn{2}{|l|}{ Capital charge } & 0.124 & 2.37 & 110 \\
\hline Fixed O\&M & & 1.000 & 0.89 & 41 \\
\hline Variable O\&M & & 1.000 & 1.27 & 59 \\
\hline Less: Credit fo & gypsum sales ${ }^{\text {b }}$ & 1.000 & -0.06 & -3 \\
\hline Less: $\mathrm{SO}_{2}$ emis & sion allowances ${ }^{c}$ & 1.000 & -0.41 & -19 \\
\hline Total & & & 4.06 & 188 \\
\hline $\begin{array}{ll}\text { a } & \text { Levelizatic } \\
& \text { structure: } \\
& \text { stock @ } 7 \\
\text { b } & \$ 1.00 / \text { ton } \\
\text { c } & \$ 150 / \text { ton }\end{array}$ & $\begin{array}{l}\mathrm{n} \text { based on } 15- \\
50 \% \text { debt @ } 8 . \\
5 \% \text { return, givi }\end{array}$ & $\begin{array}{l}\text { project life, } 38 \% \text { tax } r \\
\text { eturn, } 15 \% \text { preferred } \\
\text { weighted cost of capit }\end{array}$ & $\begin{array}{l}4 \% \text { inflation, ar } \\
\text { ck @ 7.0\% returı } \\
\text { of } 7.925 \% \text { (inclu }\end{array}$ & $\begin{array}{l}\text { the following capital } \\
\text { and } 35 \% \text { common } \\
\text { ig inflation). }\end{array}$ \\
\hline
\end{tabular}




\section{Conclusions}

The AFGD process as demonstrated by Pure Air at the Bailly Station offers a reliable and cost-effective means of achieving a high degree of $\mathrm{SO}_{2}$ emissions reduction when burning high-sulfur coals. Many innovative features have been successfully incorporated in this process, and it is ready for widespread commercial use. The system uses a single-loop cocurrent scrubbing process with in-situ oxidation to produce wallboard-grade gypsum instead of wet sludge. A novel wastewater evaporation system minimizes effluents. The advanced scrubbing process uses a common absorber to serve multiple boilers, thereby saving on capital through economies of scale.

Major results of the project are summarized below.

- $\mathrm{SO}_{2}$ removal of over 94 percent was achieved over the three-year demonstration period, with a system availability exceeding 99.5 percent.

- A large, single absorber handled the combined flue gas of boilers generating $528 \mathrm{MWe}$ of power, and no spares were required.

- Direct injection of pulverized limestone into the absorber was successful.

- Wastewater evaporation eliminated the need for liquid waste disposal.

- The gypsum by-product was used directly for wallboard manufacture, eliminating the need to dispose of waste sludge. 


\section{Abbreviations}

$\begin{array}{ll}\text { AFGD } & \text { Advanced Flue Gas Desulfurization } \\ \text { ARS } & \text { air rotary sparger } \\ \text { CAAA } & \text { Clean Air Act Amendments } \\ \text { CaCO }_{3} & \text { limestone } \\ \text { CaSO }_{3} & \text { calcium sulfite } \\ \text { CaSO }_{4} & \text { calcium sulfate (gypsum) } \\ \text { CCT } & \text { Clean Coal Technology } \\ \text { DOE } & \text { U.S. Department of Energy } \\ \text { ESP } & \text { electrostatic precipitator } \\ \text { FGD } & \text { flue gas desulfurization } \\ \text { H } & \text { SO } \\ \text { H } & \text { sulfurous acid } \\ \text { L/G } & \text { sulfuric acid } \\ \text { NIPSCO } & \text { liquid to gas } \\ \text { NO } & \text { Northern Indiana Public Service Company } \\ \text { NSPS } & \text { nitrogen oxides } \\ \text { SO } & \text { New Source Performance Standards } \\ \text { SO } & \text { sulfur dioxide } \\ \text { SR } & \text { sulfur trioxode } \\ \text { WES } & \text { stoichiometric ratio } \\ \end{array}$




\section{References}

U.S. Department of Energy. 1989. Comprehensive Report to Congress, Clean Coal Technology Program-Advanced Flue Gas Desulfurization (AFGD) Demonstration Project, proposed by Pure Air.

Pure Air. 1996. Final Report, Volume 2-Project Performance and Economics. 


\section{Bibliography}

Ashline, P.M. 1993. "A Case Study: The Commercial Deployment of Pure Air's Clean Coal Technology," Pure Air. Paper presented at Second Annual Clean Coal Technology Conference, Atlanta, Georgia, September 1993.

Henderson, J., D.C. Vymazal, D.A. Stryf, and T.A. Sarkus. 1994. "Two Years of Outstanding AFGD Performance, Pure Air on the Lake's Bailly Scrubber Facility," Pure Air, and Northern Indiana Public Service Company, and U.S. Department of Energy. Paper presented at Third Annual Clean Coal Technology Conference, Chicago, Illinois, September 1994.

Keeth, R.J., P.J. Ireland, and P.T. Radcliffe. 1991. "Economic Evaluation of 28 FGD Processes," United Engineers and Constructors, and EPRI. Paper presented at $\mathrm{SO}_{2}$ Control Symposium, sponsored by EPRI, EPA, and DOE, Washington, D.C., December 1991.

Manavizadeh, G.B., J.J. Lewnard, D.A. Stryf, and T.A. Sarkus. 1995. "Bailly Station AFGD Demonstration Program," Pure Air, Northern Indiana Public Service Company, and U.S. Department of Energy. Paper presented at Fourth Annual Clean Coal Technology Conference, Denver, Colorado, September 1995.

Radian Corporation. 1995. Plume Opacity Modeling of NIPSCO Bailly Unit 7 and 8 Stack with May 1995 Data..

Vymazal, D.C., C.B. Manavizadeh, and D.W. Smith. 1996. "Economic and Environmental Benefits of Advanced Flue-Gas Desulfurization Technology_Three Years of DOE Test Results," Pure Air. Paper presented at American Power Conference, Chicago, Illinois, April 1996.

Wrobel, B., and D.C. Vymazal. 1992 and 1993. "Acid Rain Compliance-Advanced CoCurrent Wet FGD Design for the Bailly Station," Northern Indiana Public Service Company, and Pure Air. Paper presented at First Annual Clean Coal Technology Conference, Cleveland, Ohio, September 1992, and Air and Waste Management Association Annual Meeting, Denver, Colorado, June 1993. 